\title{
ASSESING SEASONAL PRICE BEHAVIOUR OF SELECTED DRIED FISH VARIETIES IN SRI LANKA
}

\author{
Wickrama PSSL*, Koralagama DN and Sandika AL \\ Department of Agricultural Economics, Faculty of Agriculture, University of Ruhuna, Sri Lanka
}

\begin{abstract}
Dried fish plays an important role in the national economy in multiple ways including minimizing post-harvest losses of fish providing a source of animal protein, enlarging livelihoods, utilizing idling labor into the production process and as a dish, especially for rural poor. Dried fish prices have increased drastically from 2012 to 2019 compared to fish and chicken. Being the key determinant of demand, price is crucial on consumption, dried fish demand and industry performance: increasing prices, decrease the demand, which adversely effects on dried fish industry from 2012 pushing dried fish consumption to third place. Therefore, this study aims to assess the price behavior of selected dried fish varieties and appropriate price forecasting models that could be feed into policy formulation for reasonable prices and price variation during the year. A quantitative approach was adopted gathering national average price data from secondary sources such as Hector Kobbekaduwa Agrarian and Research Institute, Department of Census and Statistics and other relevant institute. Three dried fish varieties which are highly consumed by the populace were selected representing large pelagic-skipjack tuna (Katsuwonus pelamis) and double-spotted queenfish (Scomberoides lysan) and small pelagic- gold-striped sardinella (Sardinella gibbosa). Average monthly retail price data from January 2007 to December 2019 were considered to analysis. Seasonal price variation and price indices were calculated for the three varieties in terms of real market prices. Analysis revealed highest dried fish prices in June and July months, corresponding with south-west monsoon. In contrast, lower prices have been reported during the north-east monsoon for large pelagic, months of January and February. Gold-striped sardinella indicated the highest price index in middle month of the both monsoon seasons. Highest seasonal price indexes for large pelagic varieties are indicated during May-September following the south -west monsoon. The Real Market Price (RMP) of all three dried fish varieties demonstrated a fluctuating pattern with a slight increment throughout the year. The same fluctuating patterns are observed in relation to moving average price, seasonality impact removed price and seasonality around moving average price of each three varieties separately. However, prices of three varieties are strongly correlated $(r=0.941<, p=0.00)$ with each other. The cubic price forecasting model is the best fit model of price forecasting for all the analyzed varieties. Besides, the Quadratic model can be used to predict the price of analyzed large pelagic varieties. The ARIMA analysis revealed that ARIMA $(2,1,12)$ is the best fit model for price forecasting of skipjack tuna while ARIMA $(0,1,0)$ for double spotted queen and gold stripped sardinella forecasting. Having a distinct seasonality impact on dried fish prices, the policies need to be focused on price stabilizing mechanisms to assure a certain and stable performances in the dried fish industry in Sri Lanka ensuring affordability to the majority in Sri Lanka.
\end{abstract}

Keywords: dried fish, real market price, price index, price forecasting models, seasonality

\section{INTRODUCTION}

The dried fish industry in Sri Lanka operates as a cottage level industry (Koralagama and Bandara 2018; Piyasiri et al. 2018) yet plays an important role in the economy with multiple contributions including, a source of animal protein intake, enlarge employment opportunities, utilize idling labors-female in particular and reduce post-harvest losses

*Corresponding author: shalikalaksan@gmail.com
(Patterson and Ranjith 2009). The popularity of dried fish among lower income deciles in Sri Lanka has been depicted (DCS 2016). Although dried fish was only second to the fresh fish consumption, as the main animal protein source until 2012, it was overtaken by chicken thereafter (DCS 2016). Dried fish consumption is depending on the household income (Koralagama et al. 2021; Lokuge 2018; DCS 2016), with a higher price 
sensitivity (Koralagama et al. 2021). Thus, low income people tend to buy low price dried fish products from village fair and other rural dried fish markets whereas high income earners consumes expensive dried fish varieties with innovative and attractive packages under a specific brand name from hypermarkets (Faruque et al. 2012).

\section{Production and consumption}

Double-spotted queenfish (Scomberoides lysan), skipjack tuna (Katsuwonus pelamis), smooth-belly sardinella (Amblygaster clupeoides), seer fish (Scomberomorus commersoni), and giant catfish (Arlus thalassinus) are the main marine dried fish varieties produced in Sri Lanka (MFARD 2019; DCS 2016). Local production satisfies only $65 \%$ of the local demand thus, dried fish varieties such as sprats, skipjack tuna, smoothbelly sardinella and shark are being imported, which accounts for about $35 \%$ of the local demand (MFARD 2019). Consumption pattern of several dried fish varieties are different based on the type- small and large pelagic varieties (DCS 2016).
Accordingly, Skipjack tuna (113.15g), double -spotted queenfish (74.82g) and shark $(84.19 \mathrm{~g})$ are the highest consuming largepelagic varieties whereas sprats $(487 \mathrm{~g})$, smooth-belly sardinella (76.41g), gold-striped sardinella $(43.69 \mathrm{~g})$ and trenched sardinella $(22.85 \mathrm{~g})$ are the highly consuming small pelagic varieties (DCS 2016). Despite the lower production, sprat is highly consumed by Sri Lankan hence the local demand is fulfilled by the imported sprats that accounts for $72.2 \%$; approximately 23,232 Mt in 20062018 (MFARD 2019). The monthly expenditure on the highly consumed dried fish varieties are given in Table 1. Sprat importation has increased by $36 \%$ in 2018 compared to 1995.Other dried fish varieties have decreased by 70.3\% (MFARD 2019). Skipjack tuna and double spotted queen fish are the highest and second highest expenditure dried fish varieties representing large pelagic group while smooth-belly sardinella is the third highest expenditure and consumed variety representing small pelagic group (DCS 2016). Selection of the three

Table 01: Monthly household expenditure of the mostly consumed dried fish varieties (Rs.)

\begin{tabular}{|c|c|c|c|c|}
\hline Dried fish varieties ${ }^{1}$ & 2006 & 2009 & 2012 & 2016 \\
\hline \multicolumn{5}{|l|}{ Small pelagic } \\
\hline Stolephorus sp. (sprats) & 127.14 & 184.62 & 246.96 & 296.04 \\
\hline $\begin{array}{l}\text { Amblygaster clupeoides (smooth- } \\
\text { bellysardinella) }\end{array}$ & 23.78 & 27.49 & 51.22 & 50.37 \\
\hline $\begin{array}{l}\text { Sardinella gibbosa (gold-striped sar- } \\
\text { dinella) }\end{array}$ & 9.07 & 13.01 & 17.79 & 18.04 \\
\hline Amblygaster sirm (trenched sardinella) & 7.42 & 10.38 & 17.89 & 12.23 \\
\hline \multicolumn{5}{|l|}{ Large pelagic } \\
\hline $\begin{array}{l}\text { Scomberoides lysan (double-spotted } \\
\text { queenfish) }\end{array}$ & 29 & 49.89 & 66.46 & 75.43 \\
\hline Katsuwonus pelamis (skipjack tuna) & 50.58 & 62.32 & 70.12 & 84.31 \\
\hline Carcharhinus sp. (shark) & 26.25 & 47.77 & 58.3 & 75.42 \\
\hline $\begin{array}{l}\text { Carangoides fulvoguttatusf (yellow- } \\
\text { spotted trevally) }\end{array}$ & 3.1 & 3.02 & 3.92 & 4.22 \\
\hline Arlus thalassinus (giant catfish) & 13.6 & 24.86 & 28.36 & 29.44 \\
\hline Lates calcarifer (giant Sea Perch) & 0.42 & 0.78 & 1.72 & 1.07 \\
\hline $\begin{array}{l}\text { Scomberomorus commersoni (narrow- } \\
\text { barred spanish mackerel) }\end{array}$ & 2.86 & 3.69 & 3.88 & 3.97 \\
\hline
\end{tabular}

(Source: DCS 2016)

${ }^{I}$ Hereafter, this article uses the common names of the dried fish varieties instead of the scientific name 
varieties for the price analysis is based on this table and the data availability at the HARTI.

\section{Pricing and trading}

Despite the impact of the imported dried fish to the local production, the dried fish supply is seasonal following the seasonality in fisheries (Koralagama and Bandara 2018; Murray and Little 2000). Spotted sardinella (Amyblygaster sp), skipjack tuna, yellowfin tuna (Thunnus albacares), Spanish mackerel (Scombcromorous commersoni), and double spotted queenfish are comparatively lacking during the south-west monsoon (MaySeptember) whereas rockfish (Lithrinus sp.), white sardinella, spotted sardinella (Amyblygaster sp), anchovy (Anchova commersoni) and bony flying fish (Hirundichthuys coromandelensis) for the north-east monsoon (December-February) (Koralagama 2009; MFARD 2019)1. Prices of fresh fish, particularly skipjack tuna, double spotted queenfish and white sardinella are relatively high during the south-west monsoon season (MFARD 2019).

Prices of dried fish products are mainly depending on the availability of the products in the market places (Carlucci et al. 2015). Besides, dried fish prices are important to monitor industry development and market functions (Adenegan and Bolarinwa 2010). Prices have been identified as the sign of the relative scarcity or abundance of a given product; prices also serve as incentive to direct the allocation of economic resources and to a large extent they determine the structure and rate of economic growth (Aswathy and Abdussamad 2013). Information on prices is important to producers, traders and consumers to understand the market trend and better planning for policy decisions (Murray and Little 2000; Ravallion 1986). Despite the market prices follow the demand and supply theories, many scholars have researched on few other variables that influence on the pricing mechanism including the variety, market type, importation, seasonal variation of production, transport mode and quality are another paramount (Hirimutugoda et al. 2014; Hosseini et al. 2012 ; Shamsuddoha 2007).
Further, dried fish prices also vary based on the geographical area, marketing systems and the number of intermediaries and product availability (Hasan et al. 2016; Weerahewa and Kodithuwakku 2013). However, due to one or multiple factors, the dried fish prices have being increasing from 2012 pushing down the consumption to the third place from the animal protein sources. Increasing prices and declining demand affects the industry performance (Koralagama et al. 2021), affecting both processors (Koralagama and Bandara 2018) and rural consumers (DCS 2016), where both ends are marginalized. In this regard, price behavior analysis and forecasting is important on dried fish. Although the fresh fish market is fully backed by the local production, the dried fish demand is compensated by the imported dried fish varieties. However, dried fish prices are increasing (HARTI 2019; MFARD 2019). Thus, this study explores the price behavior of the mostly consumed dried fish varieties by analyzing the impact of seasonality on the prices. Further, the study attempts to calculate a seasonality index to detect the percentage share of variation/fluctuation for better forecasting and prediction that would enable for price controlling mechanism in the future for efficient policy decisions. The next section of this paper briefs the methodology carried out in data collection and analysis, which is followed by the results and discussion zooming into seasonality variations and price indices. Finally the paper concludes by highlighting the price behavior of dried fish and pragmatic solutions for the variations.

\section{MATERIALS AND METHODS Varieties and data sources}

Hector Kobbekaduwa Agrarian Research Institute (HARTI) maintains price data of eight dried fish varieties on giant catfish (Arlus thalassinus), skipjack tuna (Katsuwonus pelamis), double-spotted queenfish (Scomberoides lysan), giant sea perch (Lates calcarifer), sting ray (Dasyatis sp.), shark (Carcharhinus sp), gold-striped sardinella (Sardinella gibbosa), imported sprats (Stolephorus sp.) and narrow-barred spanish mackerel (Scomberomorus commersoni). Out of these varieties, skipjack 
tuna, double-spotted queenfish and goldstriped sardinella were considered as the highly consumed dried fish varieties in Sri Lanka (DCS 2016) representing locally produce large pelagic and small pelagic varieties (see table 01). Weekly retail price data, particularly market price data for the period of 2007-2019 available at the Hector Kobbekaduwa Agrarian Research and Training Institute of Sri Lanka, which is the main research institute with a large data bank, were used as the main data source for the analysis.

\section{Analytical procedure}

Real Market Prices (RMP) were calculated for the generalization and to extract the absolute prices avoiding inflation by using Nominal Market Price (NMP). Colombo consumer price index, which uses 2006/2007 years as the base year $(C C P I)(2006 / 2007=100)$ was considered. The CCPI gives the local government, businesses, citizens and idea about price changes in the Sri Lankan economy. Besides, the Colombo consumer price index is the widely used tool in adjusting for inflation and, by proxy, for the effectiveness of the Sri Lankan government's economic policy (Alibuhtto and Peiris 2012; Sandika 2011). The calculation procedure of RMP is given in the following equation (i).

$$
R M P=\frac{N M P * 100}{C C P I} \ldots \ldots \ldots \ldots \ldots \ldots
$$

Price is a value generated through the effect of four components namely trend, cyclical, seasonal, and random/irregular parts which are according to classical price multiplicative model as (Price $=$ Trend $\mathrm{x}$ Cyclical $\mathrm{x}$ Seasonal $\mathrm{x}$ Random/Irregular components). In dried fish price variation and production, seasonality is one of the vital characteristics (Koralagama and Bandara 2018; Hirimutugoda et al. 2014). Therefore, the analysis focused on the seasonal components thereby removing other components (viz; trend, cyclical and random) from dried fish price series. This method is important as it enables to predict the future stock price movements based on recently available data.
Moreover, it is estimated the trend $(\mathrm{T})$, cyclical (C), seasonal (S), and random (E), indices of the price series (Zhang 2013). See the below equation (ii)

$$
P=T * C * S * E
$$

Where; $\mathrm{P}=$ price, $\mathrm{T}=$ Trend component, $\mathrm{C}=$ Cyclical component, $\mathrm{S}=$ Seasonal component, $\mathrm{E}=$ Random component, $\mathrm{T}$ is expressed as a price per unit while $\mathrm{C}, \mathrm{S}$, and $\mathrm{E}$ are all indices, the linear trend is calculated as a simple linear regression of price against a time variable.

Trend regression was calculated as per the equation given below (iii). There, (a) constant and trend coefficient (b) were estimated to determine each trend

$T_{i}=a+b t_{i}$

Where; $\mathrm{Ti}=$ trend value during the period $\mathrm{I}$; a $=$ the constant-coefficient as estimated by the regression analysis; $b=$ the trend coefficient estimated by the regression; $\mathrm{ti}=$ the value of the variable (dried fish price) during the period i.

Seasonal Index (SI) is the standard indicator of price comparison, which can be used to compare the movement of prices. It shows the average price variation of products SI states on percentage price increment or decrement of the commodity within the observed time period. It helps to forecast percentage changes of profit for traders during each month of the year. See equation (iv).

$$
S I=\left(\frac{P_{i}}{C M A_{i}}\right) * 100
$$

Where: $\mathrm{Pi}=$ Price component; $\mathrm{CMA}=$ central moving average

Calculation of central moving average (CMA) is important to develop the seasonal price index. CMA is a simple, technical analytical tool. It is usually calculated to determine the trend direction of a product or to identify its support and resistance levels. CMA represents the trend and cyclical components of the 
original series, and it removes seasonality and the random factor. The formula is given below (v).

$$
\begin{array}{r}
C M A_{t}=\sum \frac{P_{i}}{n} \ldots \ldots \ldots \ldots \ldots \\
i=t-\frac{1}{2}(n-1)
\end{array}
$$

Thus, CMA will now be,

$$
\left(\sum_{i=t-6}^{i=t+5} P i+\sum_{i=t-5}^{i=t+6} P i 24\right) \div 24
$$

Where: $\mathrm{CMA}=$ Central Moving Average; $\mathrm{P}=$ Nominal price; $\mathrm{n}=$ Number of periods.

The SI is already deflated as it is calculated by dividing the nominal price series (the original price) by another price series (the SI). Seasonality Removed Price (SRP) from another price series can be calculated as in the equation (vi), it is used to remove the seasonal impact of price out of four main components in price series.

$$
S R P=\frac{P_{I}}{S I}
$$

Where, $\mathrm{SRP}=$ Seasonality removed price; $\mathrm{Pi}=$ Real price; $\mathrm{SI}=$ Seasonal index

Seasonality around moving average price (SAMAP) from another price series was calculated as follow (see equation vii),

$S A M A P=P_{i} * S I$

Where, SAMAP $=$ Seasonality around moving average price, $\mathrm{Pi}=$ Nominal $/$ Real price, $\mathrm{SI}=$ Seasonal index. It is important to remove the effect of irregular movement from the SI values. It calculates the average of SI for each month over the different years, then adjusting SI figure series by the adjusting factors.

Karl Pearson's product movement correlation coefficient has been used to assess the correlation between prices of different dried fish varieties and the same was applied to calculate the correlation by using SPSS version 22

Different time series models such as linear ( $\mathrm{Y}$ $=\mathrm{a}+\mathrm{bX})$, Quadratic $(\mathrm{Y}=\mathrm{a}+\mathrm{bx}+\mathrm{cx} 2)$ Cubic $(\mathrm{Y}=\mathrm{a}+\mathrm{bx}+\mathrm{bx} 2+\mathrm{cx} 3)$ and power were applied to the determination of the best fit model. R2was used to easy and accurate determination of suitable model. SPSS version 22 was used for the analysis.

Based on the selected best Time Series (TS) model, an appropriate price forecasting model for different types of dried fish was developed. The goodness of fit of the model was tested using coefficients of determination (R2), stationary R2, mean absolute percentage error (MAPE) and maximum absolute percentage error (MaxAPE). R-squared values for each model indicate the proportion of the variance in the dependent variable that is predictable from the independent variable. Mean Absolute Percentage Error (MAPE) indicates the how accurate a forecast system and Maximum Absolute Percentage Error (MaxAPE) represents the largest fore casting error expresses as a percentage (Zhang 2013; Majumdar 2002).

ARIMA models were used to conduct time series analysis of selected dried fish prices. 'Auto Regressive Integrated Moving Average'(ARIMA) is a forecasting algorithm based on the idea that the information in the past values of the time series can alone be used to predict the future values (Divisekara $e t$ al. 2020). ARIMA is generally utilized because of its appropriate statistical properties (Zhang 2013).

\section{RESULTS AND DISCUSSION \\ Behavior of average RMP and seasonal price index}

This section elaborates the results of the price analysis in assessing monthly real market price variation of skipjack tuna (balaya), double spotted queenfish (katta) and goldstriped sardinella (salaya). The study uses RMP; hence, NMP was converted to RMP (see equation i) (annex i for NMP). Comparison of monthly moving average and RMP variation of skipjack tuna, gold-stripped 


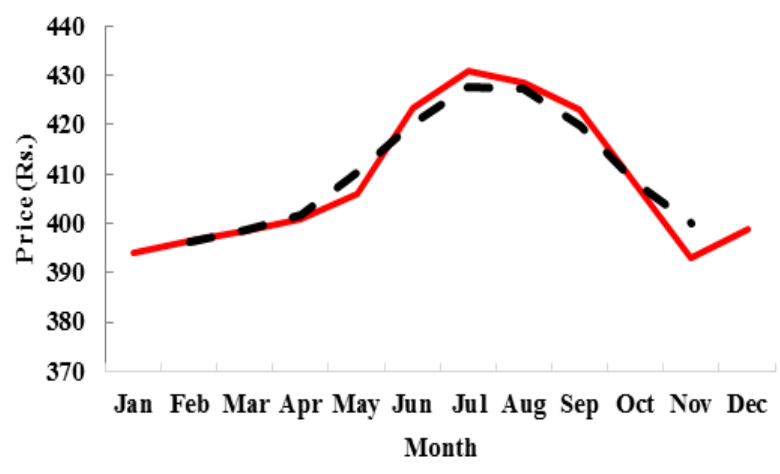

Figure A: Skipjack tuna

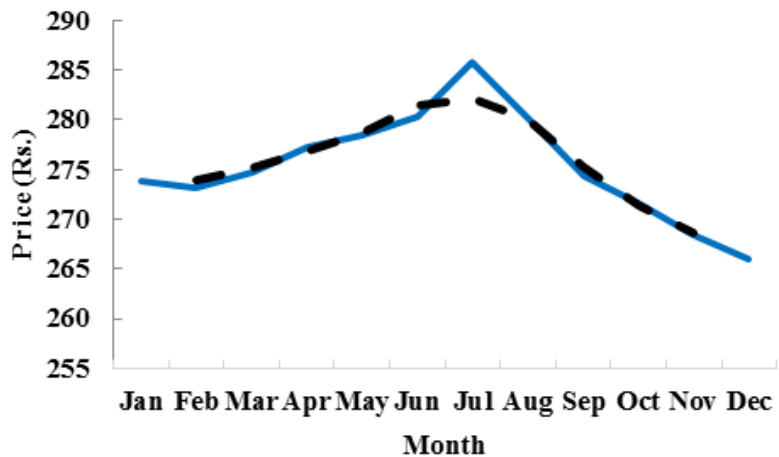

Figure B: Gold-striped sardinella

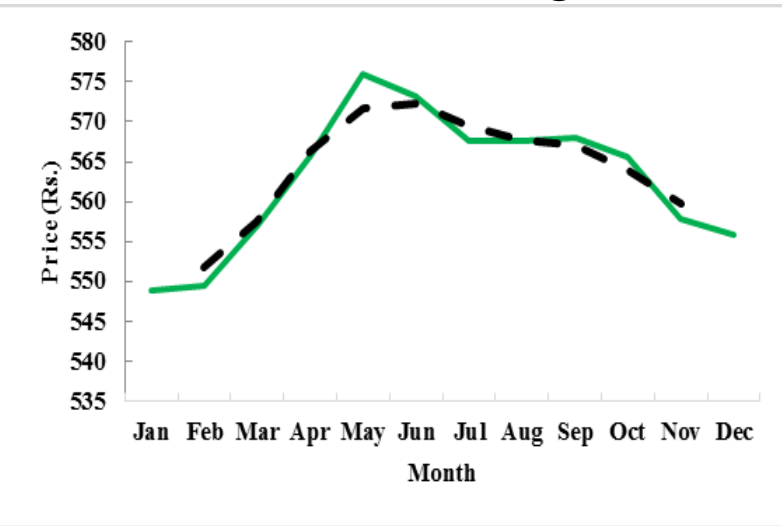

Figure C: Double-spotted queenfish

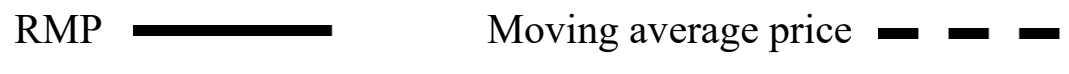

Figure 1: Monthly average RMP and moving average price variation

sardinella and double-spotted queenfish are shown in figure 01 in 2007-2019 time periods.

Prices of skipjack tuna and gold-striped sardinella reveal clear price increment in the month of July however the prices are gradually increasing from March to July and then decrease thereafter. In contrast, prices of double spotted queenfish show a clear increase of price in May where the prices are gradually increasing from January to May then slightly decrease till December. Peak prices are reported during south-west monsoon season from May to September period while the lower prices in north-east monsoon. Furthermore, gold stripped sardinella price indicate comparatively highest prices in January and February following the north-east monsoon. Price increment of gold-stripped sardinella initiate with the beginning of the north-east monsoon. Large pelagic fish varieties that used for dried fish processing come largely from southern and western provinces whereas small pelagic varieties come from western and northern region of the country (Koralagama et al. 2021; Amarasinghe 2020; MFARD 2019). Therefore seasonal climate changes in each region causes to variation of dried fish production on variation of raw fish amount (Dayalatha 2020; Koralagama 2009; Murray and Little 2000). Following low dried fish production (Murray and Little 2000), dried fish prices have increased during south-west monsoon season for large pelagic varieties and in both monsoon season for small pelagic dried fish varieties due to the low fish production (Dayalatha 2020; Koralagama 2009; Murray and Little 2000: 30; FAO 1984: 40).

Some of the former research findings related to fish and dried fish are coincided with above findings. Price of fish varied highly during the 
rainy season associated with short supply and increased demand (Pradhan et al. 2017). Furthermore, price is relatively low during the winter months on highest production following excess supply. Results of the Perera et al. (2016) revealed that the highest fish price during the middle months of the year in Sri Lanka. More fish are harvested during the winter season of Bangladesh and it causes to decline in the price of different fish varieties (Omar et al. 2014). Price of the fish is highest in the April to July month in Bangladesh due to the lowest production of fish and many religious festivals such as Ramadan and Eidul-Azha. Demand for fish is steadily increased during May to September month because of the low supply (Murray and Little 2000). Therefore, consumers' demands toward dried fish are also increased during same time from May to September as the substitute product for fish. Accordingly price of fish as well as dried fish are increased during same period (Murray and Little 2000).

Figure 2 indicates that, seasonal price index value variation of observed dried fish varieties on monthly average RMP, during the 2007-2019 time periods.

According to figure 02 , seasonal price index of skipjack tuna is indicated greater than 100 in June, July, August, September, October and December while November month is attained the lowest 98.2 seasonal price index. January, April, July, August and October month are identified as greater than $100 \mathrm{SI}$ values obtaining month for gold-striped sardinella. January month (101.4) is the highest value obtaining month and December month (98.2) is the lowest value obtaining month. Double-spotted queenfish indicates greater than $100 \mathrm{SI}$ values in May, Jun, September and October month while May month is identified as the highest SI value obtained month. Furthermore, June, July and September months are highest price increment months for skipjack tuna. Around $0.7 \%$ price increment can occur in these months for skipjack tuna. Gold stripped sardinella show $1.4 \%$ of price increment in January and double-spotted queen fish show $0.3 \%$ price increment in September month comparatively seasonal average. Skipjack tuna and goldstriped sardinella show a $1.8 \%$ price decrement in November and December month respectively. Double-spotted queen fish show $0.3 \%$ price decrement in February month comparatively seasonal average.

Highest seasonal price index variation is recorded for skipjack tuna and double spotted queenfish from June to October month. This is identical with the highest percentage of price increment of skipjack tuna and double spotted queenfish during the period (following the south-west monsoon season). The highest

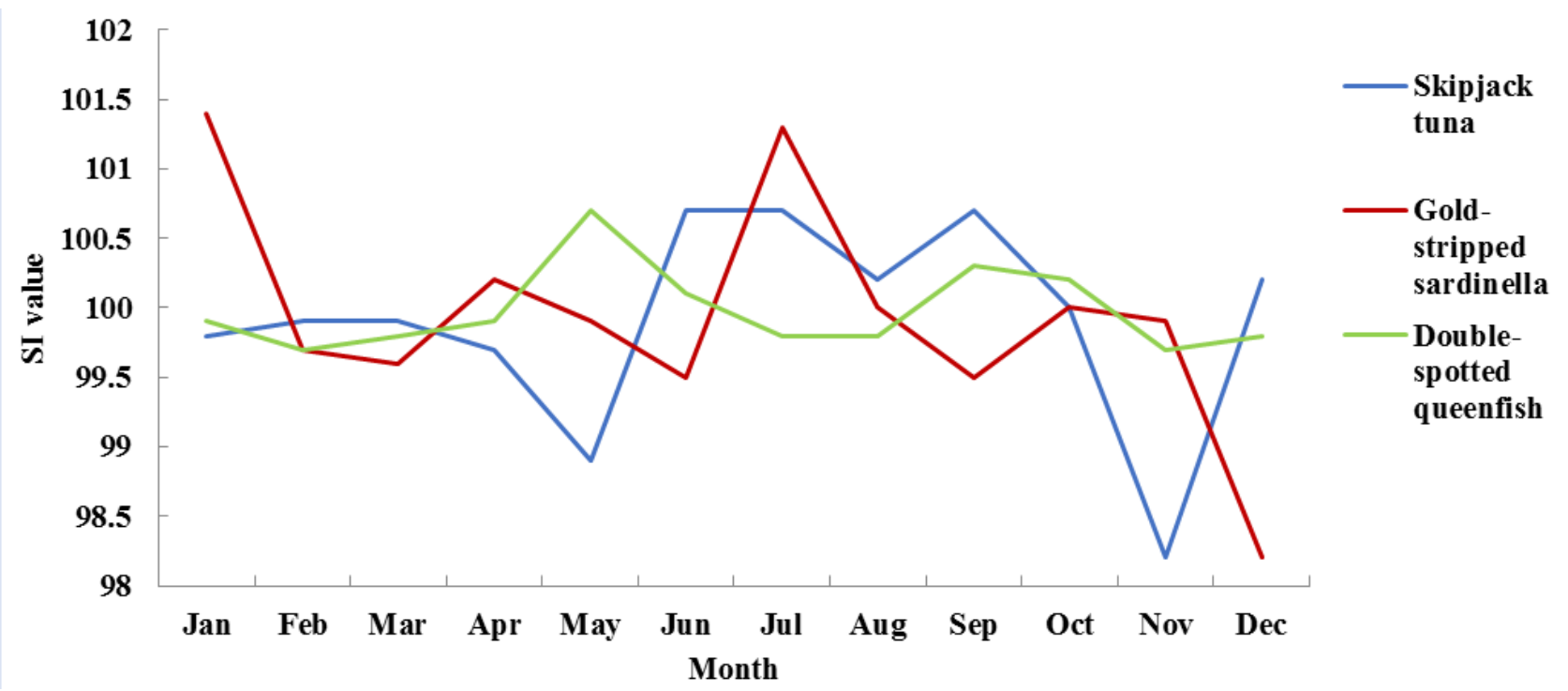

Figure 2: Seasonal price index of each month on moving average of RMP 
price variations of small pelagic-gold striped sardinella varieties are exhibited during June to August and December to February period following south-west monsoon (MaySeptember) and north-east monsoon (December-February) respectively.

It has recorded that the fish production during the south-west monsoon (May-September) and north-east monsoon (December-February) comparatively lesser than other months of the year due to adverse weather condition and low community participation for fishing (Dayalatha 2020; Murray and Little 2000: 30; FAO 1984: 40). The small-pelagic fish that used to dry are mainly coming from west and north coast and large-pelagic from south and west coast in Sri Lanka (Koralagama et al. 2021; Amarasinghe 2020; MFARD 2019). Due to the lesser fish production during south -west and north-east monsoon in northern, eastern, western and southern coast (Murray and Little 2000: 30; FAO 1984: 40), it is perceived that the large pelagic raw fish production comparatively low during southwest monsoon while small pelagic comparatively low during the both monsoon season in Sri Lanka (Koralagama 2009) so as the dried fish. Therefore, production quantity of small pelagic dried fish is comparatively decreased in both monsoon periods and large pelagic in south-west monsoon (Murray and Little 2000). Low supply of dried fish varieties such during two monsoon periods causes to highest percentage of seasonal price increment for large pelagic in south-west and small pelagic in both monsoon periods (Murray and Little 2000; FAO 1984). Similar results have been obtained by a few researches conducted on Inidan and Bangladesh fisheries (Vishwanatha et al. 2018; Omar et al. 2018), where has the same monsoon pattern as in Sri Lanka.

\section{Behavior of monthly RMP and different price components}

The behavior of monthly RMP variation of skipjack tuna, gold striped sardinella and double spotted queen fish are given in figure 03 during the 2007-2019 periods (see annex ii for NMP).

The monthly prices of all three dried fish varieties have increased continuously with fluctuating patterns during the period. Three time slots are visible namely, from January 2007 to January 2008, from January 2009 to January 2012 and from January 2015 to January 2018. Slight increases are noticeable during these time slots with a mild fluctuation. In contrast, higher price increases are reported from January 2008 to January

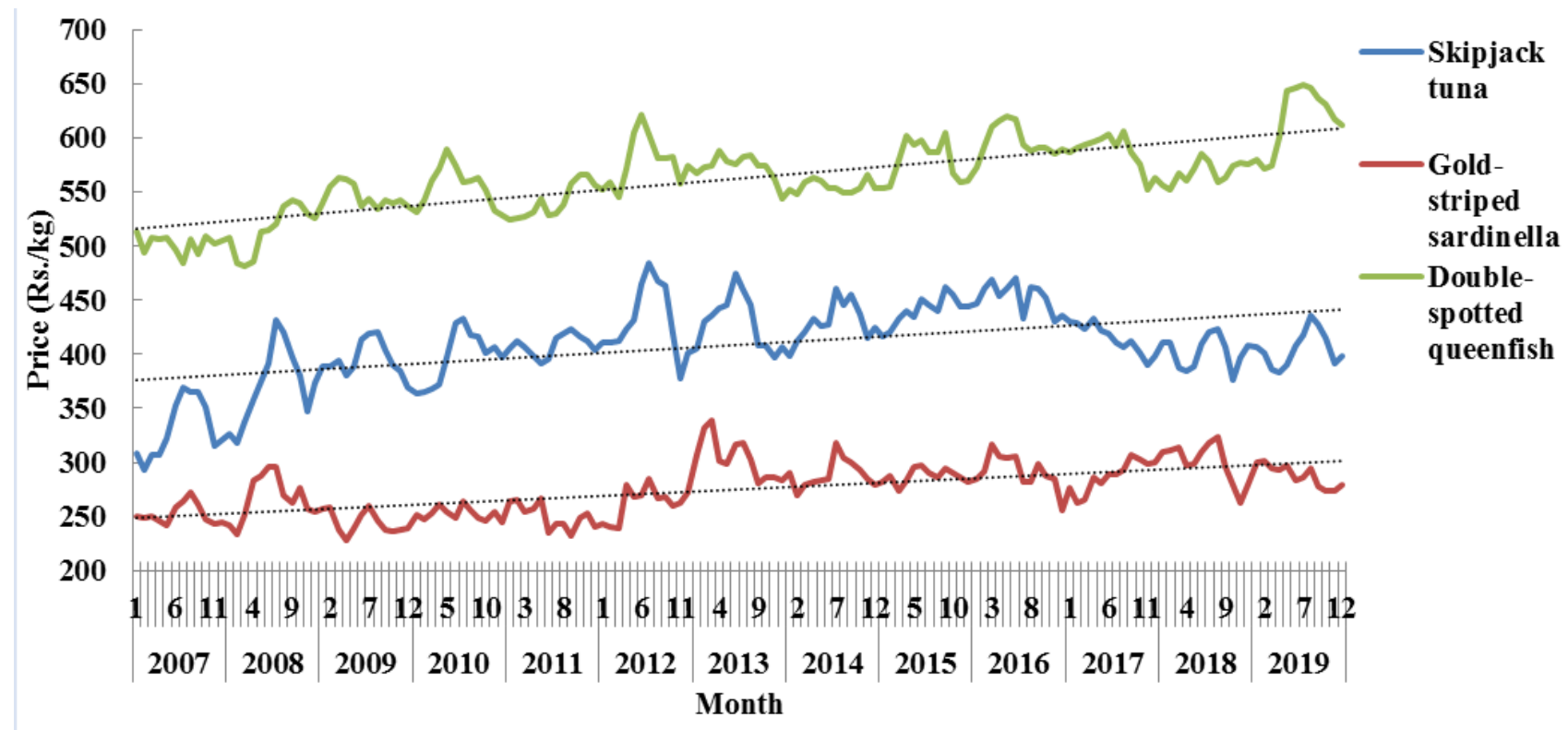

Figure 03: The behavior of monthly RMP of different dried fish varieties in 2007-2019 
2009, January 2012 to December 2014 and January 2018 to December 2019 with higher fluctuation.

RMP variation is not well maintained during the observed period of different three varieties comparatively nominal market price variation (see annex ii). It can be identified; inflation is the main factor that affects the price increment of observed dried fish varieties. Therefore, processor income levels were not increased by a considerable amount comparatively market price increment of the three dried fish varieties.

Furthermore, the nominal fish prices have expanded over time, real price is consistent and occasional in Sri Lanka market (Perera et al. 2016). There is the fluctuating pattern in nominal fish price over the years but not in real price. Thusly, the evident expanding pattern in nominal fish prices might be represented generally by rising inflation in the country rather than by issues inherent to the fish industry (Perera et al. 2016).

The comparison of real market price variation, moving average price variation, seasonality impact removed price variation and seasonality around moving average price variation of different three dried fish varieties are shown in following figure 4.

Various fluctuating pattern of different price components of each analyzed three dried fish varieties are comparatively illustrated in above figure. Besides, each price components show the same fluctuating pattern within the same dried fish variety at most of the month. Inflation is the rate at which the estimation of a price is falling and consequently, the general level of price for goods and services is rising.

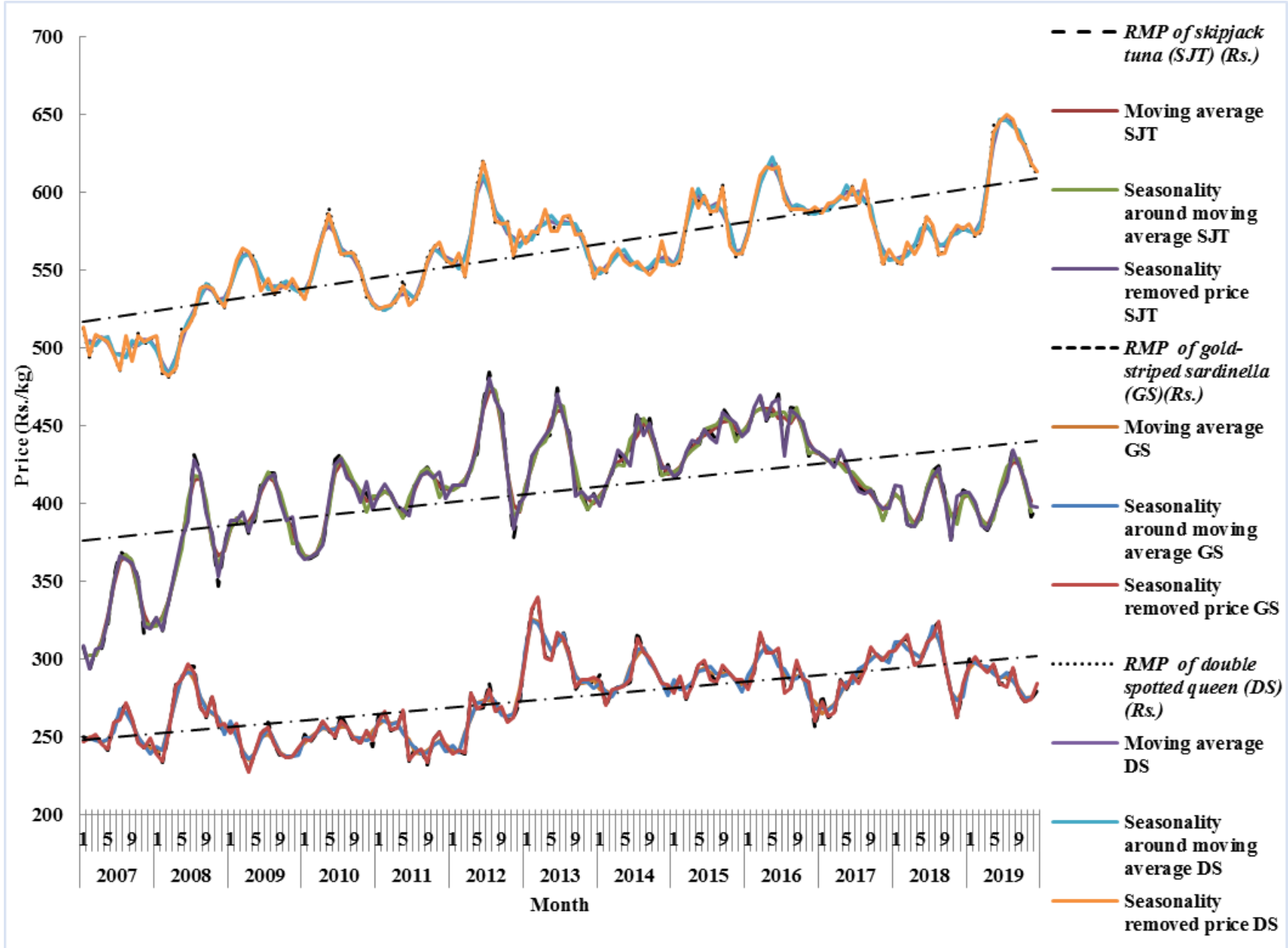

Figure 4: Different price component variation different dried fish varieties in 2007-2019 
As inflation increments to the highest levels, price dissemination isn't even symmetric. At the point when the yearly inflation rate arrives at 130 percent, there is an equivalent chance of discovering real prices above or below the market average. Accordingly, inflation is the one of critical factor which affected to variation of each price components of analyzed varieties.

\section{Relationships and forecasting models}

In statistical analysis, a correlation matrix is used to determine the degree to which a pair of dependent and independent variables are linearly related each other. A strong positive correlation is noted (table 2) among all three varieties on the highest $r$-value $(r \sim 1)$ of each variety. Price of one variety has a direct impact on the prices of other varieties as well. Price increment of one variety would increase the other varieties and vice versa. Therefore, it demonstrates that most of the factors are the same which affect to increase the price of all three varieties.

The results of Perera et al. (2016) reveals that the wholesale price and retail price of fish in the Sri Lanka market moderately correlated. The highest correlation can be seen between Colombo and Kalutara retail market fish prices while the lowest correlation between Colombo and Kandy wholesale market fish prices.

\begin{abstract}
Coefficient of determination for RMP forecasting models, R2 of the linear regression model, Quadratic model, Cubic model and Power model as shown in Table 3 (see annex iii for NMP). These models are the appropriate and most used price forecasting models in SPSS that can be used to predict the future price of commodities. Results were predicted on the value of R2 following the past researches (Sandika 2011; Kuruppu 2017). Results of main price forecasting model in SPSS revealed that the quadratic model and cubic model are the best models to forecast the price of skipjack tuna $(\mathrm{R} 2=64.9 \%)$ and the cubic model is the most suitable method to analyze the prices of goldstriped sardinella $(\mathrm{R} 2=50.6 \%)$ and double spotted queenfish $(\mathrm{R} 2=65.6 \%)$ in terms of RMP. These models show the highest R2 values out of four main suitable price forecasting models. It means a difference in one variable is strongly relation to a difference in the second variable in selected best fit models.
\end{abstract}

Suitable price forecasting models (quadratic and cubic models) for each dried fish varieties are presented in the table 4 on the results of $\mathrm{R} 2$ value, depict in the table 3 (see annex iv for NMP). Accordingly three models are prominent based on the real market price forecasting for selected dried fish varieties. Price of gold-stripped sardinella is escalating than other varieties. Skipjack tuna and double-

Table 2: Correlation matrix of different type of dried fish varieties

\begin{tabular}{llll}
\hline & Skipjack tuna & Gold-striped sardinella & $\begin{array}{l}\text { Double-spotted } \\
\text { queenfish }\end{array}$ \\
\hline $\begin{array}{l}\text { Skipjack tuna } \\
\begin{array}{l}\text { Gold-striped sardinella } \\
\text { Double-spotted queen }\end{array}\end{array}$ & $\mathrm{r}=0.941(\mathrm{p}=0.00)$ & $\mathrm{r}=0.941(\mathrm{p}=0.00)$ & $\mathrm{r}=0.958(\mathrm{p}=0.00)$ \\
$\mathrm{r}=0.958(\mathrm{p}=0.00)$ & $\mathrm{r}=0.948(\mathrm{p}=0.00)$ & $\mathrm{r}=0.948(\mathrm{p}=0.00)$ \\
\hline
\end{tabular}

Table 3: Coefficient of determination for the real price forecasting model

\begin{tabular}{lllll}
\hline Dried fish type & $\boldsymbol{R}^{\mathbf{2}}$ for real price & & & \\
\cline { 2 - 5 } & Linear regression model & Quadratic model & Cubic & Power \\
Skipjack tuna & 0.26 & 0.648 & 0.649 & 0.535 \\
Gold-striped sardinella & 0.421 & 0.431 & 0.506 & 0.331 \\
Double-spotted queenfish & 0.597 & 0.622 & 0.656 & 0.612 \\
\hline
\end{tabular}


Table 04: Price forecasting model of each dried fish varieties

\begin{tabular}{ll}
\hline Dried fish type & Price forecasting model for RMP \\
\hline Skipjack tuna & $Y^{t}=323.578+2.39 \mathrm{t}-0.013{ }^{t^{2}}$ \\
Gold-striped sardinella & $Y^{t}=260.867-0.813 \mathrm{t}+0.02$ \\
Double-spotted queenfish & $Y^{t}=485.874+2.391 \mathrm{t}-0.024$ \\
\hline
\end{tabular}

Table 05: Best fit time Series models for the real price of different dried fish varieties

\begin{tabular}{llllll}
\hline Dried fish type & Best fit model & $\begin{array}{l}\text { Stationary } \\
\text { R-squared }\end{array}$ & $\begin{array}{l}\text { R- } \\
\text { Squared }\end{array}$ & MAPE & MaxAPE \\
\hline Skipjack tuna & ARIMA $(2,1,12)$ & 0.130 & 0.84 & 2.785 & 9.753 \\
Gold-striped sardinella & ARIMA $(0,1,0)$ & 0.002 & 0.727 & 3.397 & 14.153 \\
Double-spotted queenfish & ARIMA $(0,1,0)$ & -0.003 & 0.873 & 1.679 & 6.664
\end{tabular}

Confidence Interval $=0.05$

spotted queenfish are also being imported to Sri Lanka (MFARD 2019; HARTI 2014). The price of imported dried fish mainly affect to price variation of local produce varieties (lbid). Accordingly, timely importation quantity changes are not considerably affected to price variation of gold stripped sardinella in local market. Therefore, timely price increment of gold stripped sardinella is higher than other observed varieties due to the lower competition from imported varieties.

Table 5 represents the best fit time series models for each dried fish varieties separately in terms of RMP (see annex $\mathrm{v}$ for NMP). Results indicated that R2 values are greater than 0.70 while MAPE and MaxAPE values are low for selected dried fish varieties. It revealed that percentage errors of ARIMA are least for the analysis. Therefore, ARIMA $(2,1,12)$ model is the most suitable method for Skipjack tuna forecasting. ARIMA $(0,1,0)$ method can be used to forecasting goldstriped sardinella and double-spotted queenfish.

The resulted ARIMA model in this analysis with $(0,1,0)$ is identical with the findings of Mustapa and collegues (2019), which was conducted for fresh fish and vegetables in Malaysia. Further, ARIMA model with $(2,1,1)$ is identical to fish wholesale price analysis of India. Accordingly, ARIMA models indicated satisfactory forecast value of prices lie close actual values to monitor the price behavior of fish and fish based products (Paul 2010).

\section{CONCLUSION}

This paper attempted to analyze the price behavior of three dried fish varieties, namely Katsuwonus pelamis (skipjack tuna), Scomberoides lysan (double-spotted queen fish) - large pelagic and Sardinella gibbosa (gold-stripped sardinella) - small-pelagic, which are highly consumed by Sri Lankans. The price behavior was analyzed by developing the price indices. Large pelagic dried fish varieties showed relatively higher prices in the months of June and July months and lowest in November -February, which follows the fresh fish abundance during northeast monsoon season, hence lower fresh fish prices and vice versa. Small pelagic varietiesgold-striped sardinella reported highest price in May/June while lowest in November/ December still following the monsoon impact on fresh fish availability and prices. 
Seasonal price index (SI) of skipjack tuna and double-spotted queenfish showed a high SI during the months of May-September whereas the SI is decreased from November to February. In contrast, gold stripped sardinella has higher SI in months of January and July while lowest in December. The indices follows the monsoon wind pattern, thereby the seasonality in fisheries.

Southwest monsoon (May-September) was identified as the highest percentage of price increase period for large pelagic group. Both north-east monsoon (December-February) and south-west monsoon season were identified as the highest percentage of price increase season for small pelagic varieties. In general, all three varieties showed higher prices during May-September (south-west monsoon). Impacts of imports of dried fish products to local price determination may not affect to considerably for gold stripped sardinella. Because of that reason price of gold stripped sardinella is highly increased with the time than other analyzed varieties. Coefficient of determination revealed that cubic price forecasting model was the best fit model of price forecasting for all the analyzed varieties. Besides, the Quadratic model can be used to predict the price of analyzed large pelagic varieties. The ARIMA analysis revealed that ARIMA $(2,1,12)$ was the best fit model for price forecasting of skipjack tuna while ARIMA $(0,1,0)$ for double spotted queen and gold stripped sardinella forecasting.

The study concludes that the seasonality of fresh fish is one of the important factors of variation of dried fish prices in Sri Lanka. Therefore, price stabilization policies need to be implemented during the south-west and north-east monsoon season particularly to expand storage facilities during the peak season and to ensure ceiling and floor prices, which would help to limit the speculative practices in the markets. Expansion and further development of price forecasting models can recommend for decision-making on future prices.

\section{ACKNOWLEGEMENT}

This paper is based on a study conducted for Dried Fish Matters project funded by Social Science and Humanities Research Council of Canada under the leadership of Professor Derek Johnson, Project Director, The University of Manitoba, Canada. We thank the funding agency of Dried Fish Matters project and the Dried Fish Matters-Sri Lanka project for the financial support and anonymous review for their constructive comments.

\section{Author Contribution}

WPSSL, KDN and SAL conceptualized and designed the study. WPSSL and KDN performed the experiments. WPSSL, KDN and SAL analyzed and interpret the data. WPSSL and KDN contributed in drafting the manuscript and WPSSL, KDN and SAL critically revised the manuscript.

\section{REFERENCES}

Adenegan KO and Bolarinwa AO 2010 Price Transmission and Market Integration of Fish in Oyo State. Journal of Rural Economics and Development. 19(1623 -2016-134900): 1-15.

Alibuhtto MC and Peiris TSG 2012 Modeling Colombo consumer price index (CCPI) using time series ARIMA model, 1st Annual International Research Conference. South-Eastern University, Oluvil, Sri Lanka. 10-12.

Amarasinghe O 2020 Key Zone Identification: A Study to Identify the Key Dry Fish Producing Zones in Sri Lanka: Working Paper. Dried Fish Matters. University of Ruhuna, Matara. https://api.zotero.org/ users/4955564/items/QDCLZ39Y/file/ view

Aswathy N and EM Abdussamad 2013 Price Behavior and marketing efficiency of Marine Fish in Tuticorin. Tamil Nadu. Journal of Fisheries Economics and Development. 13 (2): 29-35.

Carlucci D, Nocella G, De Devitiis B, Viscecchia R, Bimbo F and Nardone G 2015 Consumer purchasing behavior towards fish and seafood products: Patterns and insights from a 
sample of international studies. Appetite. 84: 212-227.

Dayalatha WKV 2020 Low Socio-Economic Status Among Coastal Fishing Families in Southern Sri Lanka. Journal of European Publisher. 89(1). 139-151.

Department of Census and Statistics 2016 Household Income and Expenditure Survey. Ministry of National Policies and Economic Affairs. Colombo 01, Sri Lanka. http:// www.statistics.gov.lk/HIES/ HIES2016/ HIES2016_FinalReport.pdf

Divisekara RW, Jayasinghe GJMSR and Kumari KWSN 2020 Forecasting the red lentils commodity market price using SARIMA models. SN Business \& Economics. 1(1): 1-13.

Faruque MO, Nazrul KS, Tonny US, Islam KR, Dey SC, Mona SJ and Saha D 2012 Status of an ideal dry fish market of Bangladesh: A study on Asadganj dry fish market, Chittagong. International Journal of Life Sciences Biotechnology and Pharma Research. 1(3): 214-225.

Food and Agriculture Organization 1984 Marine Small Scale Fisheries of Sri Lanka: A General Description. Madras, India. http://www.fao.org/3/ ae484e/ae484e.pdf

Hasan MM, Rasul MG, Ferdausi HJ, Hossain, MM, Shah AKMA and Bapary MAJ 2016 Present status of dried fish markets in Sylhet of Bangladesh. Journal of Progressive Agriculture. 27 (2): 235-241.

Hector Kobbekaduwa Agrarian Research and Training Institute 2014 Weekly food prices. Colombo 07 . http:// www.harti.gov.lk/index.php/en/ market-information/weekly-foodcommodities-bulletin

Hector Kobbekaduwa Agrarian Research and Training Institute 2019 Weekly food prices. Colombo 07. http:// www.harti.gov.lk/index.php/en/ market-information/weekly-foodcommodities-bulletin
Hirimuthugoda NY, Pethiyagoda NA and Madusanka ST 2014 Factors affecting the consumer preference and consumer buying behavior of dried fish: A case of Southern province in Sri Lanka. International Symposium on Agriculture and Environment. University of Ruhuna, Sri Lanka. 419421.

Hosseini SS, Nikoukar A and Dourandish A 2012 Price Transmission Analysis in Iran Chicken Market. International Journal of Agriculture Management and Development. 2(4): 243-253.

Koralagama DN, Wickrama SL and Adikary A 2021 A Preliminary Analysis of the Social Economy of Dried Fish in Sri Lanka. Dried Fish Matters. University of Ruhuna, Matara. https:// api.zotero.org/users/4955564/items/ GEP3CAJD/file/view

Koralagama DN and Bandara SP 2018 Socioeconomic issues of women dried fish processors in southern Sri Lanka. 3rd world small- scale fisheries congress, Chiangmai, Thailand. 208-210.

Koralagama, DN 2009 Coping Vulnerability: Assess the strategies with special reference to idiosyncratic shocks in the small-scale fishery in Southern Sri Lanka. Master thesis. Tromso University, Norway.

Kuruppu IV 2017 Consumer Preference and Price Behavior Analysis for Selected Rice Varieties in Sri Lanka. Applied Economics \& Business. 2017 (1): 111.

Lokuge MN 2018 Household Food Consumption and Demand for Nutrients in Sri Lanka. Master thesis. Texas Tech University, Lubbock, Texas.

Majumdar PK 2002 Statistics A tool for Social Sciences. Rawat Publications, Satyam Apts, Jain Temple Road, Jawahar Napur, Jaipur, India. 319385.

Ministry of Fisheries and Aquatic Resource Development 2019 Fisheries statistics. Colombo $10 . \quad$ https:// www.fisheries.gov.lk/ 
Murray FJ and Little DC 2000 Fisheries marketing systems and consumer preferences in Puttalam District SriLanka. Institute of Aquaculture. University of Stirling. https:// core.ac.uk/download/ pdf/11018605.pdf

Mustapa M, Ponnusamy RR and Kang HM 2019 Forecasting Prices of Fish and Vegetable using Web Scraped Price Micro Data. International Journal of Recent Technology and Engineering. 7(5): 251-256.

Omar MI, Haque SA, Sharker MR, Islam MF and Alam MA 2014 Marketing System, Seasonal Price Variation and Market Integration of Hilsha (Tenualosa Ilisha) Fish in Some Selected Areas of Bangladesh. British Journal of Marketing Studies. 2(1): 101-116.

Patterson J and Ranjitha G 2009 Qualities of commercially and experimentally sun dried fin fish;Scomberoidestol. African Journal of Food Science. 3 (10): 299-302.

Paul R K 2010 Stochastic modeling of wholesale price of rohu in West Bengal. Central Inland Fisheries Research Institute. Barrackpore, India. http://krishi.icar.gov.in/jspui/ handle/123456789/44692

Perera KB, Herath HMLK, Jayasinghe MUK, Edirisinghe JC, Udugama JMM and Wijesuriya W 2016 Price Analysis of Selected Marine Fish Available in Colombo Fish Markets, Sri Lanka Journal of Economic research. University of Jayawardhanapura. 4 (1):108-118

Piyasiri KHKL, Amarasinghe $\mathrm{O}$ and De Silva N 2018 Gender dimension in small scale fisheries development: issues in gender equity and equality: A research study carried out in Gandara, Southern Sri Lanka. Incorporating Climate Change into Ecosystem Approaches to Fisheries and Aquaculture Management in Sri Lanka and Vietnam, Norwegian Programme for Capacity Development in Higher
Education and Research for Development (NORHED).

Pradhan N, Shrestha MK, Rai S, Jha DK and Sah SK 2017 Diversity and marketing of dried fish products in Nepal. Nepalese Journal of Agriculture and Forestry University. 1:139-152.

Ravallion M 1986 Testing market integration.American Journal of Agricultural Economics. 68(1): 102109.

Sandika AL 2011 An analysis of price behaviour of rice in Sri Lanka after liberalization of economy. Tropical Agricultural Research and Extension. 12(2): $81-84$

Shamsuddoha M 2007 Supply and value chain analysis in the marketing of marine dried fish in Bangladesh and non-tariff measures (NTMs) in international trading. European Association of Agricultural Economist(EAAE) 106th seminar. Montpellier, France. 11.

Viswanatha BS, Senthiladeban R, Rajakumar M and Mallesh B 2018 Assessment of seasonal price fluctuations of marine fishes in Karnataka. International Journal of Fisheries and Aquatic Studies, 6(3): 68-172.

Weerahewa J and Kodithuwakku S 2013 Market Analysis of Dried Aquatic Products in Sri Lanka, A Report prepared for the Regional Fisheries Livelihoods Programme for South and Southeast Asia, FAO. Agribusiness Centre, University of Peradeniya, Peradeniya, Sri Lanka.

Zhang GP 2003 Time series forecasting using a hybrid ARIMA and neural network model.Journal of Neurocomputing. 50: 159-175. 